Volume 1, Number 2, 2015

\title{
Influence of Parameters of Induction Motor-Centrifugal Pump Units with Hydropaths Connected in Series on their Modes
}

\author{
Vladyslav Lysiak ${ }^{*}$ \\ Lviv Polytechnic National University, 12, S. Bandera St., Lviv, 79013, Ukraine
}

Received: November 21, 2015. Revised: December 08, 2015. Accepted: December 15, 2015.

(c) 2015 The Authors. Published by Lviv Polytechnic National University.

\begin{abstract}
Using the mathematical model of the pump station power supply system in steady-state modes developed by the author, the influence of the parameters of induction motor-centrifugal pump units with in-seriesconnected hydropaths of the pumps on their steady-state modes was studied. A comparison was drawn on the operation of a number of coupled units with different pump ratings. It was revealed that the difference in rated flow of the operating fluid in centrifugal pumps results in the fact that only the unit with the lowest operating fluid rated flow works effectively. Units with larger rated flow of the operating fluid are underutilized and work with a decreased efficiency in all modes. Viability of applying centrifugal pumps with minimal difference in operating fluid rated flow for induction motor-centrifugal pump units with in-seriesconnected hydropaths of the pumps was substantiated.
\end{abstract}

Keywords: power supply system; induction motor; centrifugal pump; pump station.

\section{Defining the research problem selected for the study}

At the present stage of mathematical modelling, there are no available effective models of a range of receivers consisting of inseparably connected devices of different physical nature with their automatic regulators taken into consideration. This does not allow making a comprehensive analysis of their modes and processes taking into account the mutual coupling that complicates development of automated control systems (ACS) and selection of their control functions. One of the tasks is to study the effect that the parameters of inter-coupled induction motor-centrifugal pump (IM-CP) units have on their modes.

\section{Analysis of recent publications and studies on the issue}

The effect of the ratings of the pumps of the inter-coupled IM-CP units on their modes is a topical issue from the point of view of generic approach. MIKE NET by DHI Water\&Environment, powerful software available today, can be used to model hydraulic processes in drinking water supply systems. This software, along with other available applications, just establishes a relationship between the parameters and reference coordinates of the mode of the pump, pipes, etc. (flow, pressures) and main energy parameters and coordinates of the mode of the substations (electricity cost, $\mathrm{kw}$ demand). However, they do not make it possible to analyse, for instance, energy losses distribution in specific elements of the pumps (diffuser, volute, sealing, etc.), motors, their mutual effect (for instance, core saturation, harmonic components of current), influence on the power supply system, etc. Based on the analysis of experimental records of pump stations mode coordinates carried out in $[1,2,3]$ it was defined that variations of pump flowrates in time are rather slow (except during the starts and stops of the equipment and emergency processes). That is why they can be considered as quasi stable values. Main part of energy consumption and considerable losses of energy

\footnotetext{
*Corresponding author. Email address:1wg@ukr.net
} 
take place right during these modes. And application of energy saving measures during these modes leads to a significant effect. The mathematical model proposed in $[4,5]$ allows solving these tasks for steady-state modes of IM-CP units.

\section{Aim of the research}

The research aims at studying the effect that the ratings of the pumps of induction motor-centrifugal pump units with in-series-connected hydropaths have on their modes, using generic approach.

\section{Results and discussion}

The electrical and hydraulic diagram of the pump station is presented in Fig. 1. As an example, two units connected in parallel by hydropaths were taken.

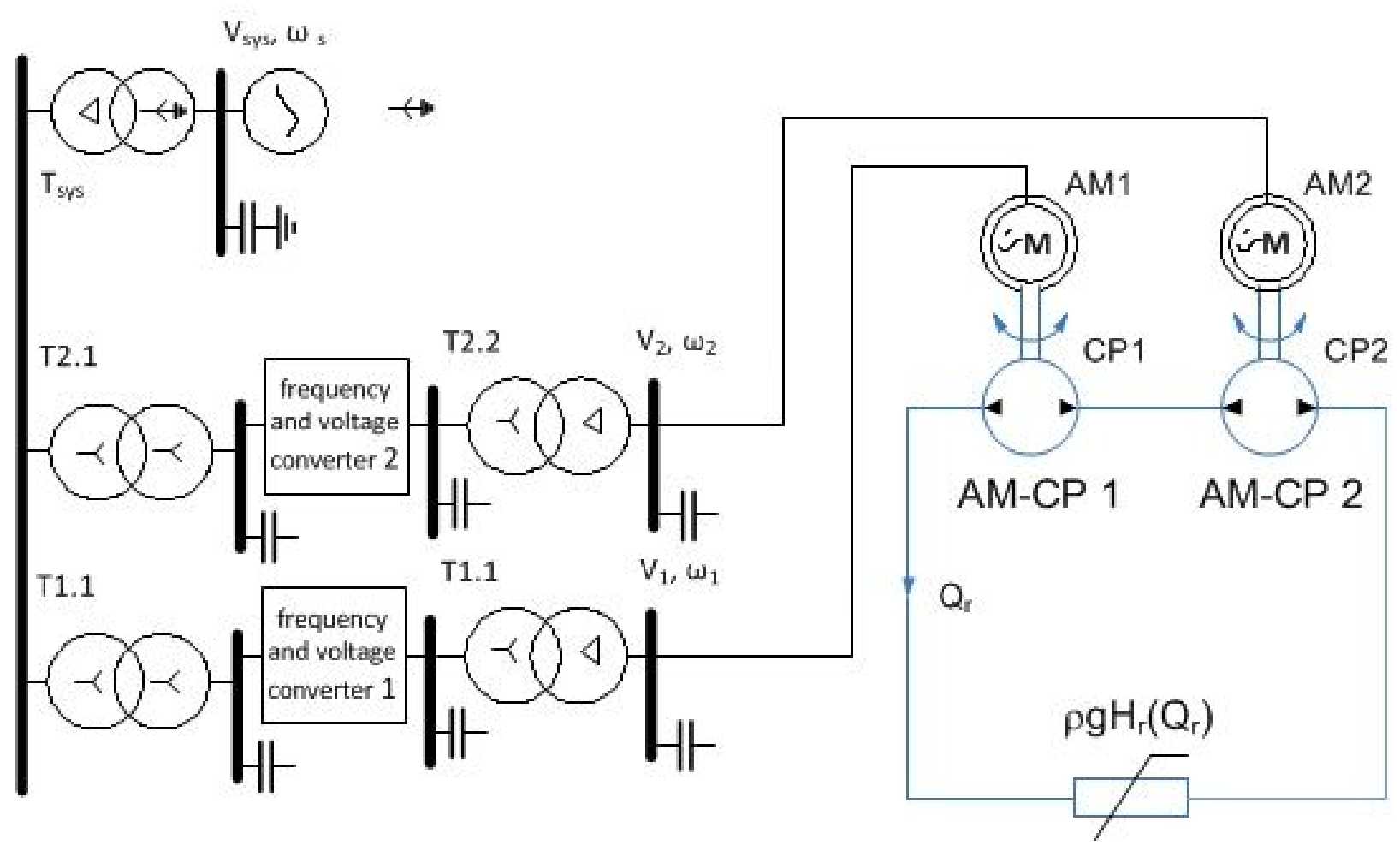

Fig. 1. Electrical and hydraulic diagram of the pump station

This study relies on the mathematical model of the pump station power supply system proposed in $[4,5]$. Equation of state is written in arbitrary base units in orthogonal coordinates, separate for IM and CP, which are respectively rigidly bound with rotating magnetic field of the IM stator $\left(d_{s}, q_{s}\right)$ and CP impeller $(d, q)$. The mentioned model was adjusted for calculation of steady-state modes of two IM-CP units with in-series-connected hydropaths (Fig. 1).

The relationship between all the centrifugal pumps of the units and the hydro network is established on the basis of $[4,5]$. The hydropaths of the two units are connected in series. Written in arbitrary base units $[4,5]$, equation expressing the relationship between them has the following form:

$$
\begin{gathered}
\mathrm{H}_{\mathrm{CP}_{1}}\left(\sqrt{\left(\mathrm{H}_{\mathrm{CPd}_{1}}\right)^{2}+\left(\mathrm{H}_{\mathrm{CP}_{1}}\right)^{2}}\right)+\mathrm{H}_{\mathrm{CPn}_{2}}\left(\sqrt{\left(\mathrm{H}_{\mathrm{CPd}_{2}}\right)^{2}+\left(\mathrm{H}_{\mathrm{CP}_{2}}\right)^{2}}\right)=\mathrm{H}_{\mathrm{CPb}} \mathrm{H}_{\mathrm{r}}\left(\mathrm{Q}_{\mathrm{r}}\right) ; \\
\mathrm{Q}_{\mathrm{CPn}_{1}} \sqrt{\left(\mathrm{Q}_{22 \mathrm{~d}_{1}}\right)^{2}+\left(\mathrm{Q}_{22 \mathrm{q}_{1}}\right)^{2}}=\mathrm{Q}_{\mathrm{CPn}_{2}} \sqrt{\left(\mathrm{Q}_{22 \mathrm{~d}_{2}}\right)^{2}+\left(\mathrm{Q}_{22 \mathrm{q}_{2}}\right)^{2}}
\end{gathered}
$$




$$
\mathrm{Q}_{\mathrm{CPn}_{1}} \sqrt{\left(\mathrm{Q}_{22 \mathrm{~d}_{1}}\right)^{2}+\left(\mathrm{Q}_{22 \mathrm{q}_{1}}\right)^{2}}=\mathrm{Q}_{\mathrm{CPb}} \mathrm{Q}_{\mathrm{r}}
$$

where for the $\mathrm{i}^{\text {th }}$ IM-CP unit, $\mathrm{Q}_{22 \mathrm{~d}}, \mathrm{Q}_{22 \mathrm{q}}$ are projections of vector of output volume fluid flow rate; $\mathrm{H}_{\mathrm{CPd}}, \mathrm{H}_{\mathrm{CPq}}$ are projections of vector of output pressure; $\mathrm{H}_{\mathrm{CPn}}, \mathrm{Q}_{\mathrm{CPn}}$ are rated hydraulic lift and volume flow rate of the pump fluid, respectively; $\mathrm{H}_{\mathrm{CPb}}, \mathrm{Q}_{\mathrm{CPb}}$ are base hydraulic lift and volume fluid flow rate, respectively; $\mathrm{Q}_{\mathrm{r}}$ is output volume fluid flow rate; $\mathrm{H}_{r}\left(\mathrm{Q}_{\mathrm{r}}\right)$ is static vertical lift of the hydro network.

For unambiguous distribution of the operating fluid between the units, functions of pressure control of in-seriesconnected hydropaths of the units are set [6]. In this case, this function is a proportional relationship between pump pressure $\mathrm{H}_{\mathrm{CPd}}, \mathrm{H}_{\mathrm{CPq}}$ and rated pump pressure:

$$
\mathrm{H}_{\mathrm{CPn}_{\mathrm{i}}}\left(\sqrt{\left(\mathrm{H}_{\mathrm{CPd}_{\mathrm{i}}}\right)^{2}+\left(\mathrm{H}_{\mathrm{CP}_{\mathrm{i}}}\right)^{2}}\right)=\mathrm{H}_{\mathrm{b}} \mathrm{k}_{\mathrm{difH}_{\mathrm{i}}} \mathrm{H}_{\mathrm{r}}\left(\mathrm{Q}_{\mathrm{r}}\right),
$$

where for the $\mathrm{i}^{\text {th }}$ IM-CP unit, $\mathrm{k}_{\mathrm{difH}}$ is factor of pressure distribution between pumps with in-series connected hydropaths.

In this case, factors $\mathrm{k}_{\mathrm{difH}}$ calculated using the method described in [6] are invariable. Their numerical values for this test case are presented in Table 2. Test calculation of a set of steady-state modes of the pump station depicted in Fig.1 was carried out by means of changing the total flow $\mathrm{Q}_{\mathrm{r}}$ in the range 0.15 to1.25 while maintaining rated pressure. Steady-state modes were calculated according to [6].

For test calculations a power system with $\mathrm{U}_{\mathrm{sys}}=110 \mathrm{kV}, \mathrm{Skz}_{\mathrm{sys}}=1,000$ MVA and ТДН-40000/110 transformer was used. Capacity values were selected in the process of calculation so as to avoid overcompensation of reactive power of IM in the calculation range. Other units whose parameters were used for test calculations are listed in Table 1.

Table 1. List of units used for test calculation

\begin{tabular}{|l|c|c|c|}
\hline \multicolumn{1}{|c|}{ Item } & Centrifugal pump & Induction motor & Transformer \\
\hline \hline 1 & $14 \mathrm{HДcH}$ & MA-38-61-6 & TC3-250/10 \\
\hline 2 & QG 300/2/100 & 4А3M-2500/10 \\
\hline 6 & $20 \mathrm{HДcH}$ & BАО2-550 & TM-1000/10T \\
\hline 9 & НМ 3600-230 & 2АЗМП-2500/6000У4 & TM-4000/10 \\
\hline
\end{tabular}

\begin{tabular}{|c|c|c|c|c|c|}
\hline Equipment configuration & $\mathrm{k}_{\mathrm{difH} 1}$ & $\mathrm{k}_{\mathrm{difH} 2}$ & Equipment configuration & $\mathrm{k}_{\mathrm{difH} 1}$ & $\mathrm{k}_{\mathrm{difH} 2}$ \\
\hline 2.2 & 0.500 & 0.500 & 1.6 & 0.580 & 0.420 \\
\hline 2.1 & 0.063 & 0.937 & 1.9 & 0.243 & 0.757 \\
\hline 2.6 & 0.954 & 0.046 & 6.9 & 0.189 & 0.811 \\
\hline 2.9 & 0.828 & 0.172 & -------- & -------- & ------- \\
\hline
\end{tabular}

Table 2. Numerical values of pressure and flow rate distribution coefficients of the pumps

Test calculations were conducted for various combinations of IM-CP units. To solve the nonlinear system of finite equations of the mathematical model, a differential method of finding zeroth-order approximations in the form of h-characteristics [7, 8] was applied. Mathcad system was applied using Levenberg-Marquardt algorithm [9]. The results of calculating steady-state modes of the pump station (Fig. 1) are presented below. 
Plots of some main indicators versus operating fluid flow rate and difference in pump ratings allow analysing the effect of ratings of the pumps of the units on their modes (Fig. 2-7). Additional indicators - load factor of the pump and difference in pump rated flows - were used for the analysis:

$$
\begin{gathered}
\mathrm{k}_{\mathrm{CP}_{\mathrm{i}}}=\mathrm{P}_{\mathrm{CP}_{\mathrm{i}}} / \mathrm{P}_{\mathrm{CP}_{\mathrm{i}}} ; \\
\mathrm{k}_{\Delta \mathrm{QCP} \mathrm{i}_{\mathrm{i}}}=\max \left(\mathrm{Q}_{\mathrm{CP}_{n_{1}}} / \mathrm{Q}_{\mathrm{CP}_{\mathrm{i}_{\mathrm{i}+1}}} ; \mathrm{Q}_{\mathrm{CP}_{\mathrm{i}+1}} / \mathrm{Q}_{\mathrm{CP}_{n_{\mathrm{i}}}}\right)-1,
\end{gathered}
$$

where for the $\mathrm{i}^{\text {th }} \mathrm{IM}-\mathrm{CP}$ unit $\mathrm{P}_{\mathrm{CPg}}, \mathrm{P}_{\mathrm{CPn}}$ are hydraulic and rated hydraulic power of the pump.

The results obtained show that for the operation of a group of IM-CP units with in-series-connected hydropaths of the pumps, only the unit with the lowest operating fluid rated flow works effectively. Units with larger rated flow of the operating fluid are underutilized in all modes. Their efficiency and load factor in particular drop dramatically as the difference in operating fluid rated flow rises. Power factor is practically non-affected by difference in pump rated flow. The difference in rated pressure was not found to have effect on mode indicators.

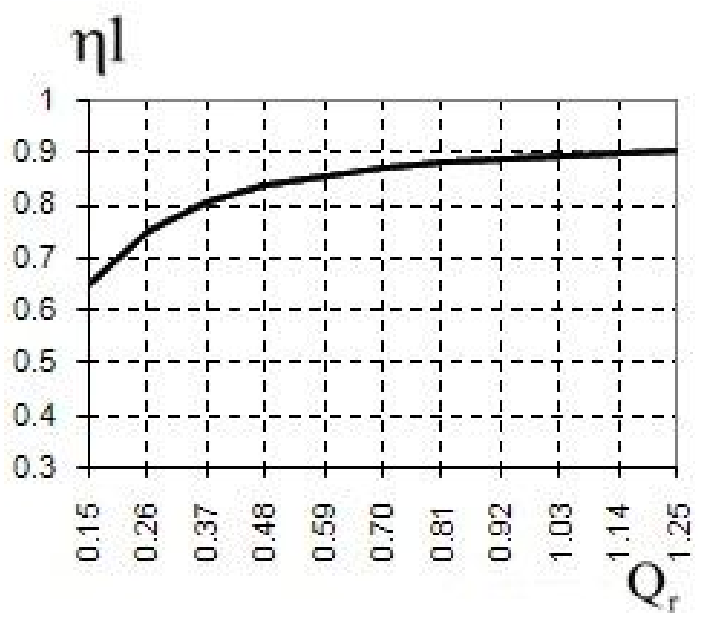

Fig. 2. Efficiency of the $1^{\text {st }} \mathrm{IM}-\mathrm{CP}$ unit

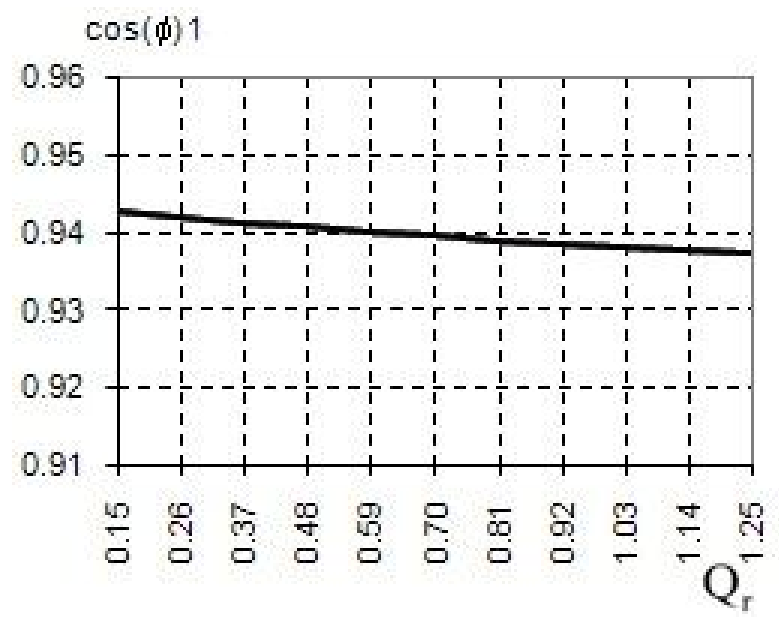

Fig. 4. $\cos (\varphi)$ for of the $1^{\text {st }}$ IM-CP unit

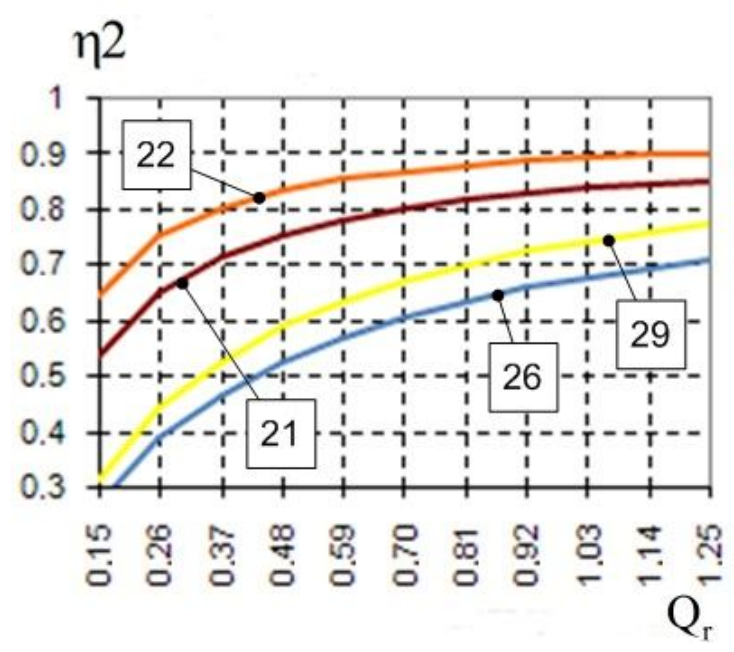

Fig. 3. Comparison of efficiency of the $2^{\text {nd }} \mathrm{IM}-\mathrm{CP}$ unit in operation with other units

\section{$\cos (\phi) 2$}

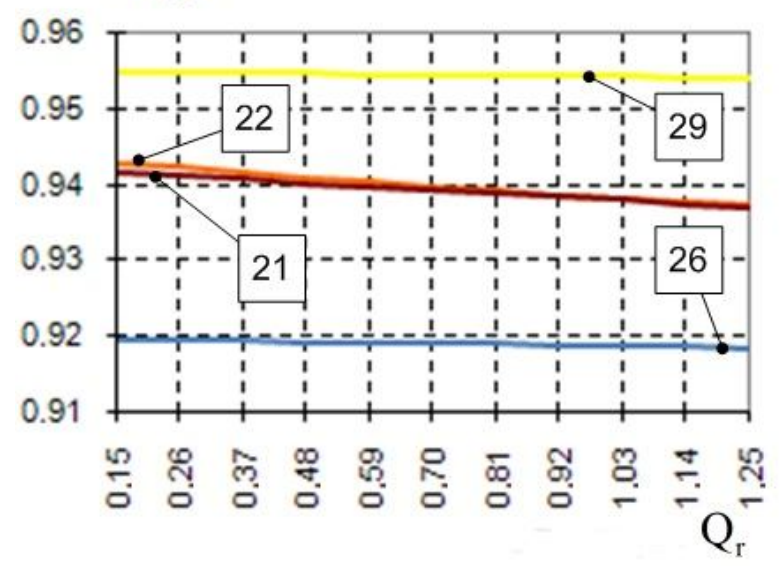

Fig. 5. Comparison of $\cos (\varphi)$ of the $2^{\text {nd }}$ IM-CP unit in operation with other units 


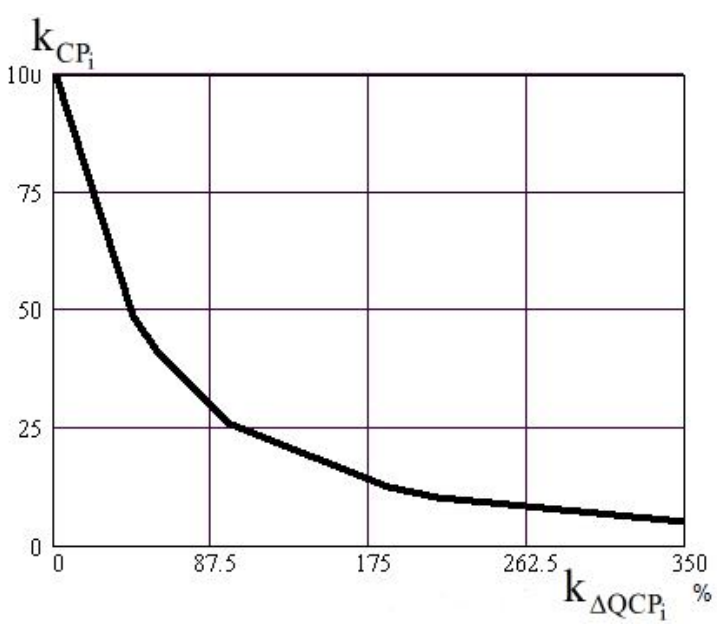

Fig. 6. Pump load factor of the underutilized unit plotted vs. difference in operating fluid rated flow

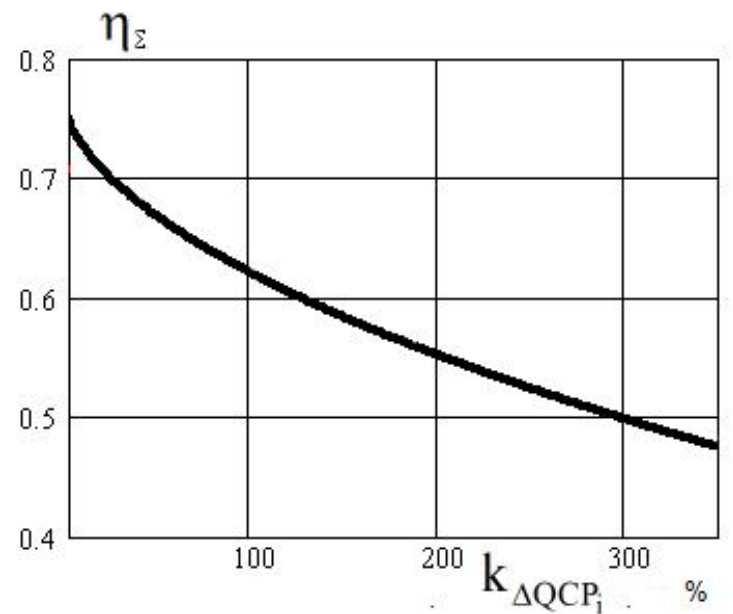

Fig. 7. Overall efficiency of two units plotted vs. difference in pump rated flow

\section{Conclusion}

The paper analysed and compared the effect of parameters of induction motor-centrifugal pump units with inseries-connected hydropaths on their modes. Difference in pump rated flow was found to have a negative impact on load factor of the units and to lower their efficiency considerably. Therefore, when selecting equipment for induction motor-centrifugal pump units with in-series-connected hydropaths, use of centrifugal pumps with minimum difference in operating fluid rated flow is a viable option.

\section{References}

[1] Borysenko V. P. Construction of energy saving system for electric drive in multi-pump station of DPVZ / V. P. Borysenko, S. V. Hryhoriev, V. P. Ovsiannikov, O. V. Golovin // XIII Int. Sci. and Eng. Conf. "Mechanical Engineering and Technological Area of XXI Century": proc. in 2 vol. - Sevastopol, 2006. - Vol. 1 - P. 138-140. (in Ukrainian)

[2] Braslavskiy I. Y. Energy saving asynchronous motor / I. Y. Draslavkiy, Z. S. Shmatov, V. N. Poliakov. - Moscow : Akademia, 2004. 256 p. (in Russian)

[3] Nikolaiev V. G. Energy-efficient ways to control the vane pump units in water supply systems in the non-stationary load [electronic resource] / V. G. Nikolaiev // Journal "Sanitary Engineering". Heading "Water Supply". - 2006. - No. 4. - P. 22-28. Access mode: http://www.abok.ru/for_spec/articles.php?nid=3355. - Screen name. (in Russian)

[4] Lysiak V. H. Mathematical modelling of steady-state modes of pump station power supply system // Tekhnichna Elektrodynamika Journal. 2008. - No. 2. - P. 43-50. (in Ukrainian)

[5] Lysiak V. H. Generalized mathematical model of stationary modes of electricity supplying system of pump station / V. H. Lysiak, P. F. Hoholiuk // Works of Institute of Electrodynamics of National Academy of Sciences of Ukraine. - 2015. - Issue. 42. - P. 22-26.351. (in Ukrainian)

[6] Hoholiuk P. F., Lysiak V. H., Kostyshyn V. S. Method of calculating distribution of volume flow rate and lift for a group of induction motor-centrifugal pump units // Electric Power Engineering and Electromechanical Systems Lviv Polytechnic National University Bulletin , 2006, No. 563, pp. 27-34. (in Ukrainian)

[7] Perkhach V. S. Mathematical Problems of Electric Power Engineering / V. S. Perkhach. - Lviv : Vyshcha Shkola Publishers, 1989. - 464 p. (in Ukrainian)

[8] Filts R. V. Mathematical foundations of the theory of electromechanical converters / R. V. Filts. - Kyiv : Naukova Dumka Publishers, 1979. 208 p. (in Russian)

[9] Ortega J. M. Iterative solution of nonlinear equations in several variables/ J. M. Ortega, W. C. Rheinboldt - New York and London: Academic Press, 2000. - 572 p. DOI: 10.1137/1.9780898719468. 


\title{
Вплив параметрів агрегатів асинхронний двигун - відцентрова помпа з послідовним сполученням гідротрактів на їхні режими
}

\author{
Владислав Лисяк \\ Національний університет “Львівська політехніка”, вул. С. Бандери, 12, Львів, 79013, Україна
}

\begin{abstract}
Анотація
За допомогою створеної автором математичної моделі електропостачальної системи помпової станції в усталених режимах досліджено вплив параметрів агрегатів асинхронний двигун - відцентрова помпа 3 послідовним сполученням гідротрактів помп на їхні усталені режими. Наведено порівняння роботи низки пар агрегатів із різними номінальними параметрами помп. Виявлено, що розбіжність номінальних витрат робочої рідини відцентрових помп призводить до того, що ефективно працює лише той агрегат, номінальна витрата робочої рідини якого $є$ меншою. Агрегати з більшою номінальною витратою робочої рідини працюють недовантаженими та зі зниженим коефіцієнтом корисної дії в усіх режимах. Обгрунтовано доцільність застосовування відцентрових помп з мінімальною розбіжністю номінальних витрат робочої рідини для роботи агрегатів асинхронний двигун - відцентрова помпа з послідовним сполученням гідротрактів помп.
\end{abstract}

Ключові слова: електропостачальна система; асинхронний двигун; відцентрова помпа; помпова станція. 